\title{
Banking Sector Development And Economic Growth In Hong Kong: An Empirical Investigation
}

SY Ho, University of South Africa, South Africa

NM Odhiambo, University of South Africa, South Africa

\begin{abstract}
In this study, we examine the dynamic relationship between bank-based financial development and economic growth in Hong Kong. We attempt to answer one critical question: Does the relationship between bank-based financial development and economic growth in Hong Kong follow a supply-leading or a demand-following response? In other words, which sector drives economic development in Hong Kong - the real sector or the nominal sector? Unlike the majority of previous studies, this study uses the newly developed ARDL-bounds testing approach to examine this linkage. The ARDL-bounds testing approach has numerous advantages over other cointegration techniques, especially when a short time-series dataset is used. In order to test the robustness of the empirical results, two proxies of bank-based financial development have been used; namely: 1) the domestic credit provided by the banking sector as a ratio of GDP and 2) the banks' deposit as a ratio of GDP. Our empirical results show that the relationship between bankbased financial development and economic growth in Hong Kong is sensitive to the proxy used to measure the banking sector development. When domestic credit provided by the banking sector is used as a proxy for bank-based financial development, a distinct supply-leading response is found to prevail. However, when the banks' deposit is used as a proxy for bank development, a demandfollowing response is found to predominate. These results hold, irrespective of whether the causality is estimated in the short run or in the long run.
\end{abstract}

Keywords: Hong Kong; Banking Sector Development; Economic Growth; ARDL-bounds Testing Approach

\section{INTRODUCTION}

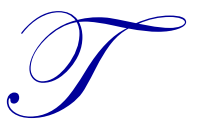

he debate regarding the causal relationship between financial development and economic growth has been ongoing since the nineteenth century. Central to the debate is whether it is the growth of the financial sector that drives the growth of the real sector or whether it is the growth of the real sector that leads the development of the financial sector (Odhiambo, 2008). The theoretical foundation of this debate can be traced back to the work of Schumpeter (1912). In an effort to analyze the importance of technological innovation in economic growth, he emphasised the crucial role of the banking system in facilitating investment in innovation and productive investment. On the contrary, Robinson (1952) argued that finance does not exert a causal impact on growth; instead, it is financial development that follows economic growth - as a result of higher demand for financial services. Although many studies have investigated the causal relationship between financial development and economic growth, the results are still ambiguous. Most of the previous empirical studies on the relationship between finance and growth have been dominated by cross-country studies - until recently. However, it is now clear that cross-country studies conducted by lumping together countries at different stages of financial and economic development may not satisfactorily address the country-specific effects.

The current study is intended to contribute to the debate on the relationship between financial development and economic growth with its focus on the Hong Kong experience. The next section discusses the trends in banking development and economic growth in Hong Kong, followed by a section giving the theoretical and empirical 
underpinning of the finance-growth nexus, a section outlining the empirical model specification, estimation techniques and the analysis of the empirical results, and finally, a conclusion.

\section{Banking Sector Development And Economic Growth in Hong Kong}

Little more than a barren rock at the beginning of the twentieth century, Hong Kong has since then developed into a vibrant international financial centre. The territory has a well-developed and highly sophisticated banking sector with a wide range of financial instruments. It has one of the highest concentrations of banking institutions in the world. Over 70 of the largest 100 banks in the world have an operation in Hong Kong (Hong Kong Monetary Authority, 2012). It maintains a three-tier banking system which comprises licensed banks, restricted licensed banks, and deposit-taking companies - all under the supervision of the Hong Kong Monetary Authority (HKMA). Currently, there are 199 authorised institutions. Among these authorised institutions, 154 are licensed banks, 20 are restricted licensed banks, and 25 are deposit-taking companies.

There are a number of significant events, including structural reforms, financial policy initiatives, and banking consolidation, that have served to shape the Hong Kong banking industry over the past few decades. Regarding the banking structure, it has moved from a monolithic system to a three-tier banking system since 1981 with further refinement taking place in 1990 (Jao, 2003). The first tier comprises licensed banks, with restricted licensed banks and deposit-taking companies as the second and the third tiers, respectively. The degree of prudential supervision varies directly with the scope of the banking business. The most strictly regulated banks - licensed banks - can take all types of deposits. For the other two tiers with less-demanding regulations, deposit-taking is confined to time deposits.

The central bank functions have been shared by a number of public and private agencies. In 1993, the Hong Kong Monetary Authority was established by merging the Exchange Fund Office with the Commissioner of Banking Office. It was widely regarded as the central bank of Hong Kong - with the responsibility for maintaining currency and banking stability.

Major financial policy initiatives were undertaken to stimulate the competition in the banking sector. They included the deregulation of interest rates, the relaxation of one branch policy for foreign banks, and the relaxation of market-entry criteria. Interest rates on bank deposits have been regulated by a set of interest rate rules issued by the Hong Kong Association of Banks (HKAB), under HKAB ordinance, since 1964 (Kwan, 2003). The interest rate rules were in full operation until 1994, when the rules were first relaxed by removing the interest ceiling on certain types of time deposits. After the local economy had recovered from the Asian financial crisis, the Hong Kong Monetary Authority announced steps to abolish the interest-rate rules entirely in order to further enhance market competition. The remaining interest-rate rules, interest-rate ceilings on time deposits of less than seven days, and all current and savings account interest-rates rules were deregulated and completed in 2001.

To provide a level playing field for local and foreign participants, the one-branch restriction for foreign banks was partially relaxed to a three-branch condition in 1999 (Jiang et al., 2003). There was a complete removal of any limitation on the number of branches and offices for foreign banks in 2001. In order to attract a broader range of domestic and international financial institutions to conduct banking business in the territory, the market-entry criteria were relaxed in 2002 (Jiang et al., 2003). These included reducing the asset-size criterion for foreign banks and relaxing the criteria for locally incorporated restricted licensed banks and deposit-taking companies to upgrade to licensed-bank status.

Financial liberalization, together with technological progress, globalization, and the motives of cost savings and revenue enhancement, has encouraged bank consolidation. There have been a number of bank mergers and acquisitions that have taken place in the territory in recent years. With the consolidation of locally incorporated licensed banks, the number of licensed banks has now decreased from 31 in 2000 to 23 in 2007 (HKMA, 2012). For example, there has been a consolidation in the ten-member banks of the Bank of China Group into the Bank of China (Hong Kong) in 2001. This has now been listed on the Hong Kong's stock exchange since July 2002 (Jiang et al., 2004:5). In addition to mergers and acquisitions between large-sized and medium-sized banks, there were deals involving smaller banks and overseas banks acquiring small local banks - as a gateway to the mainland China market. 
In addition to the consolidation of locally incorporated licensed banks, the number of authorised institutions was greatly reduced by 45\% - from 361 in 1997 to 199 in 2012 (HKMA, 2012). The decline was mainly the result of the consolidation of overseas banks and the restructuring of foreign parent banks, which had experienced financial difficulties. For example, the restructuring of Japanese and other Asian banks after the Asian financial crisis led to the consolidation and withdrawal of their overseas operation in Hong Kong.

The bank consolidation in Europe also resulted in a reduction in the number of foreign banks and their related deposit-taking companies in Hong Kong. At the same time, the bank concentration ratio, as measured by the market shares of the largest banks in deposits of the largest five banks, also increased - from 56.7 in 1992 to 71.9 in 2002 (Jiang et al., 2004:7). These indicators show that the banking sector appeared to have a high and increasing degree of concentration with potential room for further market power by large banks.

The general trend of banking development in Hong Kong, as proxied by domestic credit to private sector as the percentage of GDP (DC/GDP), indicates that the Hong Kong banking sector has developed considerably. Figure 1 shows the trends of GDP per capita and domestic credit to private sector over the period 1992-2011.

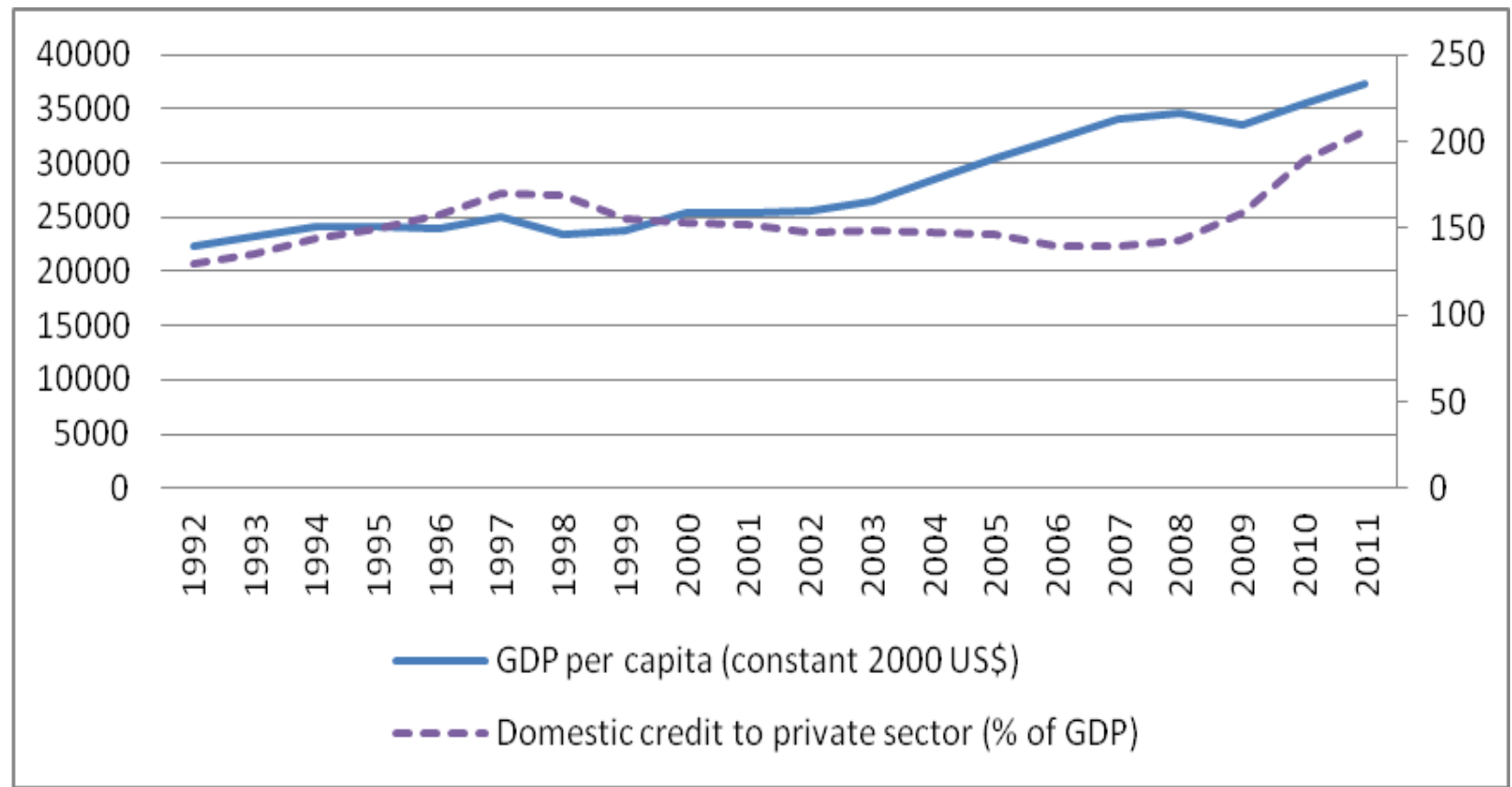

Figure 1: The Trends of GDP Per Capita and Domestic Credit to Private Sector from 1992 to 2011 Source: World Development Indicators (2012)

As shown in Figure 1, the DC/GDP increased gradually from 130 in 1992 to 170 in 1997. There was a downward adjustment after the Asian financial crisis, the burst of "dot come bubble", and the September 11 Tragedy in 2001 that led to a drop to 148 in 2002. During the years 2009-2011, a marked banking development took place in Hong Kong, with the highest number of 206 being recorded in 2011.

The growth of the banking sector in Hong Kong has also been accompanied by a rapid growth of the real sector. Hong Kong has achieved an "economic miracle" during the past few decades. As shown in Figure 1, the real per capita GDP has increased almost two-fold over the past two decades - from USD 20,188 in 1990 to USD 37,352 in 2011. The average growth rate in per capita real terms was 2.4 percent during the 1990s. This rate later increased to 3.5 percent in the $2000 \mathrm{~s}$.

When Hong Kong was ceded to the British in 1842, its economic base was an entrepôt trading port for South China and the overseas Chinese community, with only limited domestic manufacturing activities. However, the civil war on the mainland of China and the ultimate Communist victory in 1949 caused fundamental changes in 
Hong Kong. With the massive inflow of resources of labour, capital, and entrepreneurial skill - especially from Shanghai, they transformed the economy from an entrepôt to an industrial city (Krause, 1988).

In the post-war era, Hong Kong developed large export-dependent domestic manufacturing sectors. In the 1980s, it gradually moved from manufacturing into banking and financial services (Young, 1992). Hong Kong has achieved rapid economic growth during the last few decades. Together with Singapore, Taiwan, and South Korea, these now comprise the new industrialised countries (NICs) of the East.

\section{LITERATURE REVIEW}

Over the past several years, the role of financial development in economic growth has been a focus of attention which has attracted both theoretical and empirical studies to investigate the causal relationship between the two. Schumpeter (1912) argues that the role played by financial intermediaries in mobilizing funds, evaluation and selecting projects, managing risks, monitoring entrepreneurs and facilitating transactions should be seen as the critical elements in fostering technological innovations and economic growth. Goldsmith (1969) argues that the positive correlation between financial development and growth is mainly due to the efficient use of the capital stock. McKinnon and Shaw (1973) propose the significance of financial development in promoting economic growth through high capital productivity. In this paradigm, financial development is seen as a necessary precondition for economic growth. However, some economists hold skeptical views on the decisive role played by financial development. Robinson (1952) argues that finance does not exert any causal impact on growth. Instead, financial development follows economic growth as a result of higher demand for financial services. When an economy grows, more financial institutions, financial products, and services emerge in the market - in response to the higher demand for financial services. Lucas (1988) asserts that the role of the financial sector in economic growth is overemphasised. In this paradigm, finance plays a minor role in economic growth and is merely a by-product, or an outcome of growth. On the contrary, Patrick (1966) contends that a supply-leading relationship exists in the early stage of economic development, as causation runs from financial development to economic growth, while a demandfollowing relationship prevails in the later stage as the feedback causality is reversed. In this paradigm, economists believe that economic growth and financial development can complement each other, showing a bi-directional causality between financial deepening and economic growth. They maintain that financial development is indispensable to economic growth; while economic growth requires a well-functioning and efficient financial system. Another paradigm in the literature regarding the causal relationship between financial development and economic growth is that they are not causally related at all (Graff, 1999). This implies that neither of the two has any significant effect on the other and that the empirically observed correlation between them is merely the result of a historical peculiarity. In other words, even though economies grow as the financial sector grows, the two sectors follow their own individual paths.

The empirical evidence shows that there is support for all the competing perspectives. There is no general consensus regarding the direction of causality between financial development and economic growth. There are four categories in the literature regarding the causal relationship between bank-based financial development and economic growth. The first category is known as the finance-led growth response. In this case, bank-based financial development is considered to be a determinant of economic growth and the causation runs from financial development to economic growth. The empirical studies consistent with this view include those of Bittencourt (2012), Lee (2012), Colombage (2009), Odhiambo (2008), Liu and Hsu (2006), Habibullah and Eng (2006), Chang and Caudill (2005), Beck and Levine (2004), Calderón and Liu (2003), Agbetsiafa (2003), Bhattacharya and Sivasubramanian (2003), Arestis et al. (2001), Xu (2000), Levine et al. (2000), Choe and Moosa (1999), Odedokun (1999), Darrat (1999), Levine and Zervos (1998), Ahmed and Ansari (1998), Rousseau and Wachtel (1998), De Gregorio and Guidotti (1995), King and Levine (1993), and Jung (1986), among others.

The second category is known as the growth-led response, which maintains that bank-based financial development follows economic growth. In other words, economic growth causes financial institutions to change and develop. The empirical studies include those of Hassan et al. (2011), Odhiambo (2010), Colombage (2009), Chakraborty (2008), Zang and Kim (2007), Ang and McKibbin (2006), Liang and Teng (2006), Thangavelu et al. (2004), Waqabaca (2004), Agbetsiafa (2003), Shan et al. (2001), Demetriades and Hussein (1996), and Jung (1986), among others. 
The third category maintains that both bank-based financial development and economic growth Grangercause each other and that there is a bi-directional causality between these two variables. The empirical studies include those of Bangake and Eggoh (2011), Hassan et al. (2011), Wolde-Rufael (2009), Abu-Bader and Abu-Qarn (2008), Odhiambo (2005), Hondroyiannis et al. (2005), Calderón and Liu (2003), Shan et al. (2001), and Demetriades and Hussein (1996), among others.

The fourth category is that financial development and economic growth are not causally related at all. The empirical studies include those of Ibrahim (2007), Chang (2002), and Shan et al. (2001), among others. Table 1 shows the overview of previous studies on the relationship between banking development and economic growth.

Table 1: Overview of Previous Studies on the Relationship between Banking Development and Economic Growth

\begin{tabular}{|c|c|c|c|}
\hline \multicolumn{4}{|l|}{ Finance-led Growth } \\
\hline Author & $\begin{array}{c}\text { Country/ } \\
\text { Countries of Study }\end{array}$ & Methodology & Empirical Findings \\
\hline Bittencourt 2012 & $\begin{array}{l}\text { Argentina, Bolivia, Brazil and } \\
\text { Peru from } 1980 \text { to } 2007\end{array}$ & Panel time-series analysis & $\begin{array}{l}\text { Financial development promotes economic } \\
\text { growth. }\end{array}$ \\
\hline Lee 2012 & $\begin{array}{l}\text { The US, the UK, Germany, } \\
\text { France, Japan and Korea }\end{array}$ & Time-series analyses & $\begin{array}{l}\text { All countries show that financial systems } \\
\text { lead economic growth, except for Korea. }\end{array}$ \\
\hline Colombage 2009 & $\begin{array}{l}\text { Canada, Japan, Switzerland, } \\
\text { the UK and the US over the } \\
\text { period } 1995 \text { to } 2006\end{array}$ & Vector error-correction models & $\begin{array}{l}\text { A uni-directional causality running from } \\
\text { financial market development to economic } \\
\text { growth except for Canada. }\end{array}$ \\
\hline Odhiambo 2008 & $\begin{array}{l}\text { Kenya during the period } 1991- \\
2005\end{array}$ & $\begin{array}{l}\text { Co-integration and error- } \\
\text { correction techniques }\end{array}$ & $\begin{array}{l}\text { A distinct uni-directional causal flow from } \\
\text { economic growth to financial development. }\end{array}$ \\
\hline Liu \& Hsu 2006 & $\begin{array}{l}\text { Taiwan, Korea and Japan over } \\
\text { period 1981:1 to 2001:3 }\end{array}$ & $\begin{array}{l}\text { Generalized method of } \\
\text { moments and principal } \\
\text { component analysis }\end{array}$ & $\begin{array}{l}\text { Finance aggregate has positive effects on } \\
\text { Taiwan's economy. }\end{array}$ \\
\hline $\begin{array}{l}\text { Habibullah \& Eng } \\
2006\end{array}$ & $\begin{array}{l}13 \text { Asian developing countries } \\
\text { for the period 1990-1998 }\end{array}$ & $\begin{array}{l}\text { Dynamic panel Generalized } \\
\text { method of moments }\end{array}$ & $\begin{array}{l}\text { Financial intermediation promotes } \\
\text { economic growth. }\end{array}$ \\
\hline $\begin{array}{l}\text { Chang \& Caudill } \\
2005\end{array}$ & Taiwan from 1962 to 1998 & $\begin{array}{l}\text { Vector autoregressive (VAR) } \\
\text { model }\end{array}$ & $\begin{array}{l}\text { Causality running from financial } \\
\text { development to economic growth. }\end{array}$ \\
\hline Beck \& Levine 2004 & $\begin{array}{l}40 \text { countries over the period } \\
1976-1998\end{array}$ & Dynamic panel data analysis & $\begin{array}{l}\text { Expansion of both banks and stock markets } \\
\text { has a positive influence on economic } \\
\text { growth. }\end{array}$ \\
\hline $\begin{array}{l}\text { Calderón \& Liu } \\
2003\end{array}$ & $\begin{array}{l}109 \text { developing and industrial } \\
\text { countries from } 1960 \text { to } 1994\end{array}$ & $\begin{array}{l}\text { Geweke decomposition test on } \\
\text { pooled data }\end{array}$ & $\begin{array}{l}\text { Financial development enhances economic } \\
\text { growth for all countries. }\end{array}$ \\
\hline Agbetsiafa 2003 & $\begin{array}{l}\text { Eight Sub-Saharan African } \\
\text { countries }\end{array}$ & Error-correction model & $\begin{array}{l}\text { Unidirectional causality from finance to } \\
\text { growth in Ghana, Nigeria, Senegal, South } \\
\text { Africa, Togo and Zambia. }\end{array}$ \\
\hline $\begin{array}{l}\text { Bhattacharya \& } \\
\text { Sivasubramanian } \\
2003\end{array}$ & $\begin{array}{l}\text { India over the period 1970- } \\
1999\end{array}$ & Co-integration analysis & $\begin{array}{l}\text { Financial sector development leads GDP } \\
\text { and not the other way round. }\end{array}$ \\
\hline Arestis et al. 2001 & $\begin{array}{l}\text { France, Germany, Japan, } \\
\text { United Kingdom and the } \\
\text { United States }\end{array}$ & Time series analysis & $\begin{array}{l}\text { Bank-based financial systems are more able } \\
\text { to promote long-term growth than capital- } \\
\text { market-based ones. }\end{array}$ \\
\hline $\mathrm{Xu} 2000$ & $\begin{array}{l}41 \text { countries between } 1960- \\
1993\end{array}$ & $\begin{array}{l}\text { Vector auto-regressive } \\
\text { approach }\end{array}$ & $\begin{array}{l}\text { Financial development is important to } \\
\text { growth. }\end{array}$ \\
\hline Levine et al. 2000 & $\begin{array}{l}74 \text { countries during the period } \\
1960-1995\end{array}$ & $\begin{array}{l}\text { Both traditional cross-section, } \\
\text { instrumental variable } \\
\text { procedures and dynamic panel } \\
\text { techniques }\end{array}$ & $\begin{array}{l}\text { Financial intermediary development is } \\
\text { positively associated with economic } \\
\text { growth. }\end{array}$ \\
\hline Choe \& Moosa 1999 & $\begin{array}{l}\text { Korea over the period 1970- } \\
1992\end{array}$ & $\begin{array}{l}\text { Causality and non-nested } \\
\text { model selection tests }\end{array}$ & $\begin{array}{l}\text { Financial development leads economic } \\
\text { growth. }\end{array}$ \\
\hline Odedokun 1999 & $\begin{array}{l}22 \text { industrial countries and } 100 \\
\text { developing countries over the } \\
\text { period of } 1961-90\end{array}$ & $\begin{array}{l}\text { Two-stage Least Square and } \\
\text { fixed effects methods }\end{array}$ & $\begin{array}{l}\text { Expansion in the size of monetary sector is } \\
\text { found to have beneficial effects on the } \\
\text { production taking place in the real sector } \\
\text { and also on the overall economic growth. }\end{array}$ \\
\hline Darrat 1999 & $\begin{array}{l}\text { Saudi Arabia, Turkey and the } \\
\text { United Arab Emirates over the } \\
\text { period 1964-1993 }\end{array}$ & $\begin{array}{l}\text { Multivariate Granger-causality } \\
\text { tests }\end{array}$ & $\begin{array}{l}\text { Financial deepening is a necessary causal } \\
\text { factor of economic growth. }\end{array}$ \\
\hline
\end{tabular}




\begin{tabular}{|l|l|l|l|}
\hline $\begin{array}{l}\text { Levine \& Zervos } \\
1998\end{array}$ & $\begin{array}{l}47 \text { countries from 1976 to } \\
1993\end{array}$ & Cross-country regressions & $\begin{array}{l}\text { Banking development is positively and } \\
\text { robustly correlated with current and future } \\
\text { rates of economic growth. }\end{array}$ \\
\hline $\begin{array}{l}\text { Ahmed \& Ansari } \\
1998\end{array}$ & $\begin{array}{l}\text { India, Pakistan and Sri Lanka } \\
\text { over the period 1973 - 1991 }\end{array}$ & Granger causality tests & $\begin{array}{l}\text { Financial sector development causes } \\
\text { economic growth. }\end{array}$ \\
\hline $\begin{array}{l}\text { Rousseau \& Wachtel } \\
1998\end{array}$ & $\begin{array}{l}\text { The Unites States, the United } \\
\text { Kingdom, Canada, Norway } \\
\text { and Sweden over the 1870- } \\
1929 \text { period }\end{array}$ & Granger causality tests & $\begin{array}{l}\text { There is a leading role for the } \\
\text { intermediation variables in real sector } \\
\text { activity. }\end{array}$ \\
\hline $\begin{array}{l}\text { De Gregorio \& } \\
\text { Guidotti 1995 }\end{array}$ & Over 100 countries & Ordinary Least Square & $\begin{array}{l}\text { Financial development leads to improved } \\
\text { growth performance in a large cross- } \\
\text { country sample. }\end{array}$ \\
\hline King \& Levine 1993 & $\begin{array}{l}80 \text { countries over the period } \\
1960-1989\end{array}$ & $\begin{array}{l}\text { Cross-sectional approach } \\
\text { go cound predictor of economic growth. }\end{array}$ \\
\hline Jung 1986 & $\begin{array}{l}56 \text { countries, both developed } \\
\text { and developing }\end{array}$ & $\begin{array}{l}\text { Vector auto-regressive } \\
\text { approach }\end{array}$ & $\begin{array}{l}\text { The less developed countries are } \\
\text { characterized by causal direction running } \\
\text { from financial to economic development. }\end{array}$ \\
\hline
\end{tabular}

\section{Growth-led Finance}

\begin{tabular}{|c|c|c|c|}
\hline Author & $\begin{array}{c}\text { Country/ } \\
\text { Countries of Study }\end{array}$ & Methodology & Empirical Findings \\
\hline Hassan et al. 2011 & $\begin{array}{l}168 \text { countries during the } \\
\text { period of } 1980-2007\end{array}$ & $\begin{array}{l}\text { Panel estimations and } \\
\text { multivariate time-series } \\
\text { models }\end{array}$ & $\begin{array}{l}\text { A one-way causality from growth to } \\
\text { finance for Sub-Saharan Africa and East } \\
\text { Asia \& Pacific in the short run. }\end{array}$ \\
\hline Odhiambo 2010 & $\begin{array}{l}\text { Tanzania over the period } \\
1969-2006\end{array}$ & Trivariate causality model & $\begin{array}{l}\text { The growth of the real sector drives the } \\
\text { development of the financial sector. }\end{array}$ \\
\hline Colombage 2009 & $\begin{array}{l}\text { Canada, Japan, Switzerland, } \\
\text { the UK and the US over the } \\
\text { period } 1995 \text { to } 2006\end{array}$ & $\begin{array}{l}\text { Vector error-correction } \\
\text { models }\end{array}$ & $\begin{array}{l}\text { Canadian results hold that overall } \\
\text { economic growth leads to the } \\
\text { development of capital markets. }\end{array}$ \\
\hline Chakraborty 2008 & $\begin{array}{l}\text { India over the period } \\
1996 \mathrm{Q} 3 \text { to } 2005 \mathrm{Q} 1\end{array}$ & Time series analysis & $\begin{array}{l}\text { Economic growth causes financial } \\
\text { development in India. }\end{array}$ \\
\hline Zang \& Kim 2007 & $\begin{array}{l}\text { Same panel data set used by } \\
\text { Levine et al. } 2000\end{array}$ & Sims-Geweke causality tests & $\begin{array}{l}\text { Economic growth precedes subsequent } \\
\text { financial development. }\end{array}$ \\
\hline $\begin{array}{l}\text { Ang \& McKibbin } \\
2006\end{array}$ & Malaysia from 1960-2001 & $\begin{array}{l}\text { Cointegration and causality } \\
\text { tests }\end{array}$ & $\begin{array}{l}\text { Financial deepening is an outcome of the } \\
\text { growth process. }\end{array}$ \\
\hline $\begin{array}{l}\text { Liang \& Teng } \\
2006\end{array}$ & China from 1952-2001 & $\begin{array}{l}\text { Multivariate vector } \\
\text { autoregressive model }\end{array}$ & $\begin{array}{l}\text { A unidirectional causality from growth } \\
\text { to finance. }\end{array}$ \\
\hline $\begin{array}{l}\text { Thangavelu et al. } \\
2004\end{array}$ & $\begin{array}{l}\text { Australia over the period of } \\
1960-1999\end{array}$ & $\begin{array}{l}\text { Time series methodology of } \\
\text { vector autoregressive model } \\
\text { and Granger causality test }\end{array}$ & $\begin{array}{l}\text { Evidence of causality from economic } \\
\text { growth to the development of the } \\
\text { financial intermediaries. }\end{array}$ \\
\hline Waqabaca 2004 & Fiji from 1970-2000 & Vector autoregressive model & $\begin{array}{l}\text { Direction of causation running } \\
\text { predominantly from economic growth to } \\
\text { financial development. }\end{array}$ \\
\hline Agbetsiafa 2003 & $\begin{array}{l}\text { Eight Sub-Saharan African } \\
\text { countries }\end{array}$ & Error-correction model & $\begin{array}{l}\text { Unidirectional causality from growth to } \\
\text { finance in Ivory Coast and Kenya. }\end{array}$ \\
\hline Shan et al. 2001 & $\begin{array}{l}\text { Nine OECD countries and } \\
\text { China }\end{array}$ & Granger causality procedure & $\begin{array}{l}\text { One way causality from economic } \\
\text { growth to financial development is found } \\
\text { in Canada, China and Italy. }\end{array}$ \\
\hline $\begin{array}{l}\text { Demetriades \& } \\
\text { Hussein } 1996\end{array}$ & 16 countries & Time series techniques & $\begin{array}{l}\text { A few countries show economic growth } \\
\text { systematically causes financial } \\
\text { development. }\end{array}$ \\
\hline Jung 1986 & $\begin{array}{l}56 \text { countries, both developed } \\
\text { and developing }\end{array}$ & $\begin{array}{l}\text { Vector auto-regressive } \\
\text { approach }\end{array}$ & $\begin{array}{l}\text { The developed countries are } \\
\text { characterized by causal direction running } \\
\text { from economic to financial development. }\end{array}$ \\
\hline
\end{tabular}


Bi-directional

\begin{tabular}{|c|c|c|c|}
\hline Author & $\begin{array}{c}\text { Country/ } \\
\text { Countries of Study }\end{array}$ & Methodology & Empirical Findings \\
\hline $\begin{array}{l}\text { Bangake \& Eggoh } \\
2011\end{array}$ & $\begin{array}{l}71 \text { developed and developing } \\
\text { countries over the period of } \\
1960-2004\end{array}$ & $\begin{array}{l}\text { Panel vector error-correction } \\
\text { models }\end{array}$ & $\begin{array}{l}\text { Confirms results of a bi-directional } \\
\text { causality between finance and growth. }\end{array}$ \\
\hline Hassan et al. 2011 & $\begin{array}{l}168 \text { countries during the } \\
\text { period of } 1980-2007\end{array}$ & $\begin{array}{l}\text { Panel estimations and } \\
\text { multivariate time-series } \\
\text { models }\end{array}$ & $\begin{array}{l}\text { A two-way causality relationship } \\
\text { between finance and growth for most } \\
\text { regions in the short run except for Sub- } \\
\text { Saharan and East Asia \& Pacific. }\end{array}$ \\
\hline $\begin{array}{l}\text { Wolde-Rufael } \\
2009\end{array}$ & $\begin{array}{l}\text { Kenya for the period 1966- } \\
2005\end{array}$ & Granger causality test & $\begin{array}{l}\text { Three out of the four measures of } \\
\text { financial development show two-way } \\
\text { Granger causality. }\end{array}$ \\
\hline $\begin{array}{l}\text { Abu-Bader \& Abu- } \\
\text { Qarn } 2008\end{array}$ & $\begin{array}{l}\text { Egypt during the period } \\
1960-2001\end{array}$ & $\begin{array}{l}\text { Trivariate vector } \\
\text { autoregressive (VAR) } \\
\text { framework }\end{array}$ & $\begin{array}{l}\text { Financial development and economic } \\
\text { growth are mutually causal. }\end{array}$ \\
\hline Odhiambo 2005 & Tanzania & $\begin{array}{l}\text { Johansen-Juselius } \\
\text { cointegration method and } \\
\text { vector error-correction } \\
\text { mechanism }\end{array}$ & $\begin{array}{l}\text { There is bidirectional causality between } \\
\text { financial development and economic } \\
\text { growth. }\end{array}$ \\
\hline $\begin{array}{l}\text { Hondroyiannis et } \\
\text { al. } 2005\end{array}$ & $\begin{array}{l}\text { Greece during the period } \\
1986-1999\end{array}$ & $\begin{array}{l}\text { Vector autoregressive (VAR) } \\
\text { framework }\end{array}$ & $\begin{array}{l}\text { There exists a bidirectional causality } \\
\text { between finance and growth in the long } \\
\text { run. }\end{array}$ \\
\hline $\begin{array}{l}\text { Calderón \& Liu } \\
2003\end{array}$ & $\begin{array}{l}109 \text { developing and } \\
\text { industrial countries from } \\
1960 \text { to } 1994\end{array}$ & $\begin{array}{l}\text { Geweke decomposition test } \\
\text { on pooled data }\end{array}$ & $\begin{array}{l}\text { Evidence of bidirectional causality is } \\
\text { found when the sample is split into } \\
\text { developing and industrial counties. }\end{array}$ \\
\hline Shan et al. 2001 & $\begin{array}{l}\text { Nine OECD countries and } \\
\text { China }\end{array}$ & Granger causality procedure & $\begin{array}{l}\text { Bi-directional causality is found in } \\
\text { Australia, Denmark, Japan, the US and } \\
\text { the UK. }\end{array}$ \\
\hline $\begin{array}{l}\text { Demetriades \& } \\
\text { Hussein } 1996\end{array}$ & 16 countries & Time series techniques & $\begin{array}{l}\text { Most of the evidence supports the view } \\
\text { of bi-directional relationship. }\end{array}$ \\
\hline
\end{tabular}

No Relationship

\begin{tabular}{|l|l|l|l|}
\hline \multicolumn{1}{|c|}{ Author } & \multicolumn{1}{|c|}{$\begin{array}{c}\text { Country/ } \\
\text { Countries of study }\end{array}$} & \multicolumn{1}{c|}{ Methodology } & \multicolumn{1}{c|}{ Empirical Findings } \\
\hline Ibrahim 2007 & $\begin{array}{l}\text { Malaysia over the period } \\
\text { from 1985-2003 }\end{array}$ & Time series analysis & $\begin{array}{l}\text { An insignificant relation between } \\
\text { development of financial intermediary } \\
\text { and GDP. }\end{array}$ \\
\hline Chang 2002 & $\begin{array}{l}\text { Mainland China over period } \\
\text { 1987Q1 to 1999Q4 }\end{array}$ & $\begin{array}{l}\text { Multivariate vector } \\
\text { autoregressive models }\end{array}$ & $\begin{array}{l}\text { The results suggest independence } \\
\text { between financial development and } \\
\text { economic growth. }\end{array}$ \\
\hline Shan et al. 2001 & $\begin{array}{l}\text { Nine OECD countries and } \\
\text { China }\end{array}$ & Granger causality procedure & $\begin{array}{l}\text { No Granger causality, in either direction, } \\
\text { is found in France and New Zealand. }\end{array}$ \\
\hline
\end{tabular}

\section{ESTIMATION TECHNIQUES AND EMPIRICAL ANALYSIS}

Before the proxies of bank-based financial development and real GDP per capita were tested for cointegration - using the ARDL-bounds testing approach - the data sets of these variables were tested for stationarity using the Philips-Peron, ADF and ADF-GLS tests. All the data used in this study span the period from 1980 to 2011 and were obtained from the various issues of the International Financial Statistics (IFS) Yearbook and World Development Indicators. The results of the stationarity tests in levels are presented in Table 2. 
Table 2: Stationarity Tests of Variables in Levels

\begin{tabular}{|l|c|c|}
\hline \multicolumn{1}{|c|}{ Variable } & No Trend \\
\hline Stationarity Tests of Variables in Levels - Phillips-Perron (PP) Test \\
\hline Ly/N & 0.009940 & -1.342222 \\
\hline LDCPB/GDP & -1.151153 & -1.712698 \\
\hline LBD/GDP & 0.063565 & -2.430138 \\
\hline Stationarity Tests of Variables in Levels - Dickey-Fuller - GLS Test \\
\hline Ly/N & 0.298443 & -1.742057 \\
\hline LDCPB/GDP & -1.215006 & -1.731733 \\
\hline LBD/GDP & -0.422384 & -2.563316 \\
\hline Stationarity Tests of Variables in Levels - ADF Test & -1.548146 \\
\hline Ly/N & 0.169499 & -1.615598 \\
\hline LDCPB/GDP & -1.280145 & -2.766237 \\
\hline LBD/GDP & 0.063565 & \\
\hline
\end{tabular}

Notes:

1) The truncation lag for the PP tests is based on Newey and West (1987) bandwidth.

2) $* *$ and $* * *$ denote $5 \%$ and $1 \%$ levels of significance, respectively.

3) Critical values for Dickey-Fuller GLS test are based on Elliot-Rothenberg-Stock (1996, Table 1).

As shown in Table 2, the Phillips-Perron, ADF and ADF-GLS tests conducted on the two proxies of bank development and economic growth reject the stationarity in levels. Based on these results, we can conclude that the variables are not integrated of order zero $[\mathrm{I}(0)]$. The variables are, therefore, differenced once in order to test for stationarity on differenced variables. The results of the stationarity tests on the first difference are reported in Table 3.

Table 3: Stationarity Tests of Variables on First Difference

\begin{tabular}{|l|c|c|}
\hline \multicolumn{1}{|c|}{ Variable } & No Trend & \multicolumn{1}{c|}{ Trend } \\
\hline Stationarity Tests of Variables on First Difference - Phillips-Perron (PP) Test & $-3.720750^{* *}$ \\
\hline DLy/N & $-3.759457 * *$ & $-3.722142^{* *}$ \\
\hline DLDCPB/GDP & $-4.113504 * * *$ & $-3.705473^{* *}$ \\
\hline DLBD/GDP & $-4.238172 * * *$ & $-3.953571 * * *$ \\
\hline Stationarity Tests of Variables on First Difference - Dickey-Fuller - GLS Test & $-3.429576^{* *}$ \\
\hline DLy/N & $-3.795388^{* * *}$ & $-3.446662^{* *}$ \\
\hline DLDCPB/GDP & $-3.086406 * * *$ & $-3.281011^{* *}$ \\
\hline DLBD/GDP & $-3.321442^{* * *}$ & $-3.68524 * *$ \\
\hline Stationarity Tests of Variables on First Difference - ADF Test & $-5.517308^{* * *}$ \\
\hline DLy/N & $-3.026626 * * *$ & \\
\hline DLDCPB/GDP & $-3.419717 * *$ & \\
\hline DLBD/GDP & $-4.241010 * * *$ & \\
\hline
\end{tabular}

Notes:

1) The truncation lag for the PP tests is based on Newey and West (1987) bandwidth.

2) $* *$ and $* * *$ denote $5 \%$ and $1 \%$ levels of significance, respectively.

3) Critical values for Dickey-Fuller GLS test are based on Elliot-Rothenberg-Stock (1996, Table 1).

The results of the unit root tests, reported in Table 3, show that all three variables are integrated of order 1 and not of order two - or higher.

\section{Cointegration Test - ARDL-bounds Testing Procedure}

In order to test for the existence of co-integration between the two proxies of bank development and economic growth, the recently developed ARDL-bounds testing approach is used. The ARDL model used in this study can be expressed as follows (see Odhiambo, 2009a): 
Model 1 - Causality between DLCPB and DLy/N

$\Delta I n y / N_{t}=a_{0}+\sum_{i=1}^{n} a_{1 i} \Delta I n y / N_{t-i}+\sum_{i=0}^{n} a_{2 i} \Delta I n B D C P B / G D P_{t-i}+a_{3} \operatorname{Iny} / N_{t-1}+a_{4} \operatorname{InDCPB} / G D P_{t-1}+\mu_{1 t}$

$\triangle I n D C P B / G D P_{t}=\beta_{0}+\sum_{i=1}^{n} \beta_{1 i} \Delta I n D C P B / G D P_{t-i}+\sum_{i=0}^{n} \beta_{2 i} \operatorname{Iny} / N_{t-i}+\beta_{3} \operatorname{Iny} / N_{t-1}+\beta_{4} \operatorname{InDCPB} / G D P_{t-1}+\mu_{2 t}$

Model 2- Causality between DLBD/GDP and DLy/N

$$
\begin{aligned}
& \Delta \operatorname{Iny} / N_{t}=a_{0}+\sum_{i=1}^{n} a_{1 i} \Delta \operatorname{Iny} / N_{t-i}+\sum_{i=0}^{n} a_{2 i} \Delta \operatorname{InBD} / G D P_{t-i}+a_{3} \operatorname{Iny} / N_{t-1}+a_{4} \operatorname{InBD} / G D P_{t-1}+\mu_{1 t} \ldots \ldots \ldots . . . \\
& \Delta \operatorname{InBD} / G D P_{t}=\beta_{0}+\sum_{i=1}^{n} \beta_{1 i} \Delta \operatorname{InBD} / G D P_{t-i}+\sum_{i=0}^{n} \beta_{2 i} \operatorname{Iny} / N_{t-i}+\beta_{3} \operatorname{In} y / N_{t-1}+\beta_{4} \operatorname{In} B D / G D P_{t-1}+\mu_{2 t} \ldots \ldots
\end{aligned}
$$

where $\mathrm{y} / \mathrm{N}=$ Real GDP per capita, $\mathrm{DCPB} / \mathrm{GDP}=$ Domestic credit provided by the banking sector as a \% of GDP, $\mathrm{BD} / \mathrm{GDP}=\mathrm{Banks}$ deposit as a $\%$ of GDP, and $\Delta=$ first difference operator.

In order to test for the cointegration relationship, using the ARDL-bounds testing approach, two steps are followed. The first step involves examining the order of lags on the first differenced variables in equations (1) and (2) - using the Akaike Information Criterion (AIC) and the Schwartz-Bayesian Criterion (SBC). The results of our AIC and SBC tests (not reported here) show that the optimal lag of Model 1 is three, while that of Model 2 is lag one. In the second step, we apply the bounds F-test to equations (1) and (2) in order to establish whether there exists any long-run relationship between the variables under consideration. The results of the bounds test are reported in Table 4.

\begin{tabular}{|c|c|c|c|c|c|c|}
\hline Dependent Variable & \multicolumn{2}{|c|}{ Function } & \multicolumn{4}{|c|}{ F-test Statistic } \\
\hline \multicolumn{7}{|l|}{ Model 1 - BDCP/GDP and y/N } \\
\hline $\mathrm{DLy} / \mathrm{N}$ & \multicolumn{2}{|c|}{ DLy/N(DLBDCP/GDP ) } & \multicolumn{4}{|c|}{2.250} \\
\hline DLBDCP/GDP & \multicolumn{2}{|c|}{ DLBDCP/GDP(DLy/N) } & \multicolumn{4}{|c|}{$8.960 * * *$} \\
\hline \multicolumn{7}{|l|}{ Model $2-$ BD/GDP and $y / N$} \\
\hline $\mathrm{DLy} / \mathrm{N}$ & \multicolumn{2}{|c|}{ DLy/N(DLBD/GDP) } & \multicolumn{4}{|c|}{$5.766 * * *$} \\
\hline DLBD/GDP & \multicolumn{2}{|c|}{ DLBD/GDP (DLy/N) } & \multicolumn{4}{|c|}{2.600} \\
\hline \multicolumn{7}{|l|}{ Asymptotic Critical Values } \\
\hline & \multicolumn{2}{|c|}{$1 \%$} & & & \multicolumn{2}{|c|}{$10 \%$} \\
\hline & $\mathrm{I}(0)$ & $\mathrm{I}(1)$ & $\mathrm{I}(0)$ & $\mathrm{I}(1)$ & $\mathrm{I}(0)$ & $\mathrm{I}(1)$ \\
\hline Pesaran et al. (2001), p. 300, Table CI(ii) Case II & 4.94 & 5.58 & 3.62 & 4.16 & 3.02 & 3.51 \\
\hline
\end{tabular}

Table 4: Bounds F-test for Cointegration

Note: $* * *$ denote statistical significance at the $5 \%$ and $10 \%$ levels, respectively.

The results reported in Table 4 show that there exists a long-run relationship between each of the two proxies of the banking sector development and economic growth. Specifically, the results show that there is a unique co-integrating vector between banking sector development and economic growth in both Model 1 and Model 2. This finding is confirmed by the F-statistics in the DLBC/GDP equation (Model 1) and the DLy/N equation (Model 2), which are found to be both greater than the critical F-statistics at the $1 \%$ level of significance.

\section{Granger Non-Causality Test}

Following the confirmation of a long-run co-integration relationship between bank development proxies and economic growth, we proceed to the next step - examining for causality between these variables. For this purpose, the following dynamic Granger-causality model, based on the error-correction mechanism, is used (see also Odhiambo, 2008, Narayan and Smyth, 2008; Odhiambo, 2010). 
Model 1 - Causality between DLCPB/GDP and DLy/N

$$
\begin{aligned}
& \Delta \operatorname{Iny} / N_{t}=\delta_{0}+\sum_{i=1}^{n} \delta_{1 i} \Delta \operatorname{Iny} / N_{t-i}+\sum_{i=0}^{n} \delta_{2 i} \Delta \operatorname{InDCPB} / G D P_{t-i}+E C M_{t-1}+v_{1 t} \ldots \ldots \ldots \text { (5) } \\
& \Delta I n D C P B / G D P_{t}=\lambda_{0}+\sum_{i=1}^{n} \lambda_{1 i} \Delta I n D C P B / G D P_{t-i}+\sum_{i=0}^{n} \lambda_{2 i} \Delta \operatorname{Iny} / N_{t-i}+E C M_{t-1}+v_{2 t} \ldots \ldots \text { (6) }
\end{aligned}
$$

Model 2- Causality between DLBD/GDP and DLy/N

$$
\begin{aligned}
& \Delta \operatorname{Iny} / N_{t}=\delta_{0}+\sum_{i=1}^{n} \delta_{1 i} \Delta \operatorname{In} y / N_{t-i}+\sum_{i=0}^{n} \delta_{2 i} \Delta \operatorname{InBD} / G D P_{t-i}+E C M_{t-1}+v_{1 t} \ldots \ldots \ldots \text { (7) } \\
& \Delta \operatorname{InBD} / G D P_{t}=\lambda_{0}+\sum_{i=1}^{n} \lambda_{1 i} \Delta \operatorname{InBD} / G D P_{t-i}+\sum_{i=0}^{n} \lambda_{2 i} \Delta \operatorname{Iny} / N_{t-i}+E C M_{t-1}+v_{2 t} \ldots \ldots \ldots \ldots \text { (8) }
\end{aligned}
$$

where $\mathrm{ECM}_{\mathrm{t}-1}=$ the lagged error-correction term obtained from the long-run equilibrium relationship.

From equations 5-8, the direction of the causality between the two proxies of bank-based financial development and economic growth is determined by the F-statistic and the lagged error-correction term. While the F-statistic represents the short-run causal effect, the t statistic on the coefficient of the lagged error-correction term

\begin{tabular}{|c|c|c|c|c|}
\hline Dependent Variable & Causal Flow & F-statistic & t-test on ECM & $\mathbf{R}^{2}$ \\
\hline \multicolumn{5}{|c|}{ Model 1 - DBDCP/GDP and Dy/N } \\
\hline $\mathrm{Dy} / \mathrm{N}$ & $\mathrm{DBDCP} / \mathrm{GDP} \rightarrow \mathrm{Dy} / \mathrm{N}$ & 2.2538 & - & 0.77 \\
\hline DBDCP/GDP & $\mathrm{Dy} / \mathrm{N} \rightarrow \mathrm{DBDCP} / \mathrm{GDP}$ & $4.9109 * *$ & $-2.523 * *$ & 0.79 \\
\hline \multicolumn{5}{|c|}{ Model 2 - DBD/GDP and Dy/N } \\
\hline $\mathrm{Dy} / \mathrm{N}$ & $\mathrm{DBD} / \mathrm{GDP} \rightarrow \mathrm{Dy} / \mathrm{N}$ & $7.1432 * * *$ & $-2.750 * *$ & 0.78 \\
\hline DBD/GDP & $\mathrm{Dy} / \mathrm{N} \rightarrow \mathrm{DBD} / \mathrm{GDP}$ & 1.5319 & - & 0.69 \\
\hline
\end{tabular}
represents the long-run causal relationship (see Narayan and Smyth, 2006; Odhiambo, 2008; Odhiambo, 2009b). The results of these causality tests are reported in Table 5.

Table 5: Granger Non-causality Tests

Note: $* * *$ denotes statistical significance at the $1 \%$ level.

The results reported in Table 5 show that the causal relationship between bank-based financial development and economic growth in Hong Kong depends on the proxy used to measure the level of financial development. When the domestic credit provided by the banking sector is used as a proxy for bank-based financial development, a distinct supply-leading response is found to prevail. The long-run causal flow from bank development to economic growth is confirmed by the coefficient of the lagged error-correction term, which is found to be negative and statistically significant. The short-run causal flow, on the other hand, is confirmed by the F-statistic, which is found to be statistically significant. However, when the banks' deposit is used as a proxy for bank development, causality changes from a supply-leading response to a demand-following response. In other words, economic growth is found to Granger-cause bank development - both in the short run and in the long run. The short-run causal flow is supported by the F-statistic in the bank-development equation, which is confirmed to be statistically significant. The long-run causality, on the other hand, is confirmed by the coefficient of the lagged error-correction term in the bankdevelopment equation, which is confirmed to be negative and statistically significant. 


\section{CONCLUSION}

In this study, we have examined the relationship between bank-based financial development and economic growth - using the Hong Kong time-series data. The study has attempted to answer one critical question: Does the relationship between bank-based financial development and economic growth in Hong Kong follow a supplyleading or a demand-following response? Hong Kong has developed into a vibrant international financial centre. The territory has a well-developed and highly sophisticated banking sector with a wide range of financial instruments. Unfortunately, very few studies have attempted to examine the dynamic causal relationship between bank-based financial development and economic growth in Hong Kong. Some of the previous studies also suffer from methodological deficiencies. For example, some previous studies have over-relied either on the residual-based co-integration test associated with Engle and Granger (1987) or on the maximum-likelihood test associated with Johansen (1988) and Johansen and Juselius (1990). Yet, it is now well known that these co-integration techniques may not be appropriate when the sample size is too small (see Narayan and Smyth, 2005; Odhiambo, 2009a). Using the newly developed ARDL-bounds testing approach, the current study finds that the relationship between bankbased financial development and economic growth is sensitive to the proxy used to measure the banking-sector development. When the domestic credit provided by the banking sector is used as a proxy for bank-based financial development, a distinct supply-leading response is found to prevail. However, when the banks deposit is used as a proxy for bank development, a demand-following response is found to prevail. These results hold, irrespective of whether the causality is estimated in the short run or in the long run.

\section{AUTHOR INFORMATION}

Sin-Yu Ho received both her Bachelor's degree and Master's degree in Economics from the University of Hong Kong. She is currently working as a lecturer in the Economics Department at the University of South Africa (UNISA). Before joining UNISA in 2009, she worked for the University of Hong Kong, where she was responsible for teaching courses related to microeconomic theory, macroeconomic theory, and economics development of China. Her research interests include monetary economics and development economics. E-mail: hosy@unisa.ac.za /alicehosinyu@gmail.com

Professor Nicholas M. Odhiambo holds a Ph.D. (Economics) degree from Stellenbosch University (South Africa) and a Masters degree in Economics from the University of Dar-es-salaam (Tanzania). His research profile is broad, rich and multifaceted. During the past ten years, he has published more than 65 articles in 31 recognised journals. Professor Odhiambo is an NRF-rated researcher and is listed in a number of international bibliographies and databases. He is currently working as a Research Professor of Economics and Chair of Growth, Poverty and Policy Modelling (GPPM) Research flagship at the University of South Africa (UNISA). E-mail: odhianm@unisa.ac.za / nmodhiambo@gmail.com (Corresponding author)

\section{REFERENCES}

1. Abu-Bader, S. and Abu-Qarn, A.S. (2008), "Financial Development and Economic Growth: the Egyptian Experience," Journal of Policy Modeling, 30, 887-898.

2. Agbetsiafa, D.K. (2003), "The Finance Growth Nexus: Evidence from Sub-Saharan Africa," International Advances in Economic Research, 9 (2).

3. Ahmed, S. and Ansari, M. (1998), "Financial Sector Development and Economic Growth: the South Asian Experience," Journal of Asian Economics 9 (3), 503-517.

4. $\quad$ Ang, J.B. and Mckibbin, W.J. (2007), "Financial Liberalization, Financial Sector Development and Growth: Evidence from Malaysia," Journal of Development Economics, 84, 215-233.

5. $\quad$ Arestis, P., Demetriades, P.O. and Luintel, K. B. (2001), "Financial Development and Economic Growth: The Role of Stock Markets," Journal of Money, Credit and Banking, 33(1): 16-41.

6. Bangake, C. and Eggoh, J.C. (2011), "Further Evidence on Finance-growth Causality: A Panel Data Analysis," Economic Systems, 35, 176-188.

7. Beck, T. and Levine, R. (2004), "Stock Markets, Banks, and Growth: Panel Evidence,” Journal of Banking \& Finance, 28, 423-442. 
8. Bhattacharya, P. and Sivasubramanian, M. (2003), "Financial Development and Economic Growth in India: 1970-1971 to 1998-1999," Applied Financial Economics, 13 (12).

9. Bittencourt, M. (2012), "Financial Development and Economic Growth in Latin America: Is Schumpeter Right?" Journal of Policy Modelling, 34, 341-355.

10. Calderon, C. and Lin, L. (2003), "The Direction of Causality between Financial Development and Economic Growth," Journal of Development Economics, 72, 321-334.

11. Chakraborty, I. (2008), "Does Financial Development Cause Economic Growth? The Case of India," South Asia Economic Journal, 9, 109-139.

12. Chang, T. (2002), "Financial Development and Economic Growth in Mainland China: a Note on Testing Demand-following or Supply-leading Hypothesis," Applied Economics Letters, 9:13, 869-873.

13. Chang, T. and Caudill, S. B. (2005), "Financial Development and Economic Growth: the Case of Taiwan," Applied Economics, 37:12, 1329-1335.

14. Choe, C. and Moosa, I.A. (1999), "Financial System and Economic Growth: the Korean Experience," World Development 27(6):1069-1082.

15. Colombage, S. (2009), "Financial markets and economic performances: Empirical evidence from five industrialized economies," Research in International Business and Finance, 23, 339-348.

16. Darrat, A.F. (1999), "Are Financial Deepening and Economic Growth Causally Related? Another Look at the Evidence," International Economic Journal 13 (3), 19-35.

17. De-Gregorio, J. and Guidotti, P. (1995), "Financial Development and Economic Growth," World Development 23 (3), 433-448.

18. Demetriades, P.O. and Hussein, K.A. (1996), "Does Financial Development Causes Economic Growth? Time Series Evidence from 16 Countries," Journal of Development Economics, Vol. 51, 387-411.

19. Elliot G., Rothenberg T., Stock J. (1996) "Efficient Tests for an Autoregressive Unit Root”, Econometrica, Vol. 64, pp. 813-836

20. Engle, R.F. and Granger, C.W.J. (1987), "Co-integration and Error Correction: Representation, Estimation and Testing," Econometrica, 55, pp. 251-276.

21. Goldsmith, R. W. (1969). Financial structure and development. New Haven, CT: Yale Univ. Press.

22. Graff, M. (1999). "Financial Development and Economic Growth—a New Empirical Analysis," Dresden discussion paper series in Economics, Nr. 5/99 (Technische Universitat Dresden).

23. Habibullah, M.S. and Eng, Y. (2006), "Does Financial Development Cause Economic Growth? A Panel Data Dynamic Analysis for the Asian Developing Countries," Journal of the Asia Pacific Economy 11 (4), 377-393.

24. Hassan, M.K., Sanchez, B. and Yu, J.S. (2011), "Financial Development and Economic Growth: New Evidence from Panel Data", The Quarterly Review of Economics and Finance 51 (2011) 88-104.

25. Hondroyiannis, G., Lolos, S. and Papapetrou, E. (2005), "Financial Markets and Economic Growth in Greece, 1986-1999," Int. Fin. Markets, Inst. and Money 15:173-188.

26. Hong Kong Monetary Authority, http://www.hkma.gov.hk/eng/key-functions/banking-stability/bankingpolicy-and-supervision/three-tier-banking-system.shtml, retrieved on 28 July 2012.

27. Ibrahim M. H., (2007), "The Role of the Financial Sector in Economic Development: the Malaysian Case," International Review of Economics (2007) 54: 463-483.

28. International Financial Statistics Yearbook, IMF, various issues.

29. Jao, Y.C. (2003), "Financial Reform in Hong Kong," The International Handbook on Financial Reform. Edward Elgar Publishing, Cheltenham (Chapter 6).

30. Jiang, G., Tang, N., Law, E. and Sze, A. (2003), "Determinants of Bank Profitability in Hong Kong," HKMA Research Memorandums.

31. Jiang, G., Wong, J., Tang, N. and Sze, A. (2004), "Banking Sector Competition in Hong Kong Measurement and Evolution over Time," HKMA Research Memorandums.

32. Johansen, S. (1988), "Statistical Analysis of Cointegration Vectors," Journal of Economic Dynamics and Control 12: 231-54.

33. Johansen, S. and Juselius, K. (1990), "Maximum Likelihood Estimation and Inference on Cointegration with Applications to the Demand for Money", Oxford Bulletin of Economics and Statistics 52: 169-210.

34. Jung, W. (1986), "Financial Development and Economic Growth: International Evidence," Economic Development and Cultural Change 34, 333-346 (January). 
35. King, R. and Levine, R. (1993), "Finance and Growth: Schumpeter Might be Right," Quarterly Journal of Economics 108 (3), 713-737.

36. Krause, L. B. (1988), "Hong Kong and Singapore: Twins or Kissing Cousins?” Economic Development and Cultural Change, Vol. 36, No. 3, S45-S66.

37. Kwan, S.H. (2003), "Impact of Deposit Rate Deregulation in Hong Kong on the Market Value of Commercial Banks," Journal of Banking \& Finance, Vol. 27, Issue 12, December 2003, Pages 2231-2248.

38. Lee, B.S. (2012), "Bank-based and Market-based Financial Systems: Time-series Evidence," Pacific-Basin Finance Journal, 20, 173-197.

39. Levine, R., Loayza, N. and Beck, T. (2000), "Financial Intermediation and Growth: Causality and Causes," Journal of Monetary Economics, 46, 31-77.

40. Levine, R. and Zervos, S. (1998), "Stock Markets, Banks and Economic Growth" American Economic Review 98 (June): 537-58.

41. Liang, Q. and Teng, J.Z. (2006), "Financial Development and Economic Growth: Evidence from China," China Economic Review, 17, 395-411.

42. Liu, W. C. and Hsu, C.M. (2006), "The Role of Financial Development in Economic Growth: the Experiences of Taiwan, Korea, and Japan," Journal of Asian Economics, 17, 667-690.

43. Lucas Jr., R. E. (1988), "On the Mechanics of Economic Development," Journal of Monetary Economics, $22,3-42$.

44. McKinnon, R. I. (1973), Money and Capital in Economic Development, Washington, D.C., The Brookings Institution.

45. Narayan, P. K., and Smyth, R. (2008), "Energy Consumption and Real GDP in G7 Countries: New Evidence from Panel Cointegration with Structural Breaks", Energy Economics, Vol. 30, pp. 2331-2341.

46. Narayan, P. K., and Smyth, R. (2005), "Electricity Consumption, Employment and Real Income in Australia: Evidence from Multivariate Granger Causality Tests," Energy Policy, Vol. 33, pp. 1109-1116.

47. Narayan, P. K., and Smyth, R. (2006), "Higher Education, Real Income and Real Investment in China: Evidence from Granger Causality Tests", Education Economics, Vol. 14, pp. 107-125.

48. Newey, W.K., West, K.D.(1987), "A Simple, Positive Semi-Definite, Heteroskedasticity and Autocorrelation Consistent Covariance Matrix”, Econometrica, Vol. 55, pp. 703-8.

49. Odedokun, M.O. (1999), "Alternative Econometric Approaches for Analyzing the Role of the Financial Sector in Economic Growth: Time-series Evidence from LDCs," Journal of Development Economics 50 (1), 119-146.

50. Odhiambo, N.M. (2005), "Financial Development and Economic Growth in Tanzania: a Dynamic Causality Tests," African Finance Journal 7(1):1-17

51. Odhiambo, N.M. (2008), "Financial Depth, Savings and Economic Growth in Kenya: A Dynamic Causal Linkage," Economic Modelling, 25 (4), 704-713.

52. Odhiambo, N.M. (2009a), "Energy Consumption and Economic Growth in Tanzania: An ARDL Bounds Testing Approach", Energy Policy, Vol. 37, Issue 2.

53. Odhiambo, N.M. (2009b), "Finance-Growth-Poverty Nexus in South Africa: A Trivariate Causality Test “, Journal of Socio-Economics, Vol. 48, Issue 2

54. Odhiambo, N.M. (2010), "Interest Rate Reforms, Financial Deepening and Economic Growth in Tanzania: a Dynamic Linkage,” Journal of Economic Policy Reform, 13:2, 201-212.

55. Patrick, H.T. (1966), "Financial Development and Economic Growth in Underdeveloped Countries," Economic Development and Cultural Change, 14(1):174-189.

56. Pesaran, M., Shin, Y., and Smith, R. (2001), "Bounds Testing Approaches to the Analysis of Level Relationships", Journal of Applied Econometrics, Vol. 16, pp. 289-326.

57. Robinson, J., (1952), The Generalisation of the General Theory in: The Rate of Interest and other Essays. McMillian, London.

58. Roussean, P.L. and Wachtel, P. (1998), "Financial Intermediation and Economic Performance: Historical Evidence from Five Industrialized Countries," Journal of Money, Credit and Banking, 30 (4), 1933-57.

59. Schumpeter, J.A., (1912), Theorie derWirtschaftlichen Entwicklung [The Theory of Economic Development]. Dunker \& Humblot, Leipzig. (Translated by Redvers Opie, Cambridge, MA, Harvard University Press, 1934).

60. Shan, J., Morris, A. and Sun, F. (2001), "Financial Development and Economic Growth: an Egg-andChicken Problem?" Review of International Economics, 9(3), 443-454. 
61. Shaw, E. S. (1973), Financial Deepening in Economic Development. New York: Oxford University Press.

62. Thangavelu, S. M., Jiunn, A.B. and James (2004), "Financial Development and Economic Growth in Australia: an Empirical Analysis,” Empirical Economics (2004) 29:247-260.

63. Waqabaca, C. (2004), "Financial Development and Economic Growth in Fiji," Working Paper 2004/03 (December). Economics Department, Reserve Bank of Fiji.

64. World Development Indicators (2012), World Bank, Washington, D.C.

65. Wolde-Rufael, Y. (2009), "Re-examining the financial development and economic growth nexus in Kenya," Economic Modelling, 26, 1140-1146.

66. Xu, Z. (2000), "Financial Development, Investment and Economic Growth,” Economic Inquiry 38 (2), 331-344.

67. Young, A. (1992), "A Tale of Two Cities: Factor Accumulation and Technical Change in Hong Kong and Singapore," NBER Macroeconomics Annual 1992, Vol. 7, 13-64.

68. Zang, H. and Kim, Y.C. (2007), "Does Financial Development Precede Growth? Robinson and Lucas Might Be Right," Applied Economics Letters 14:15-19. 